\title{
SEMANTIC CHANGE OF VERB MEANING
}

\author{
Donoxon Usmonova
}

English Language Faculty, Fergana State University, Uzbekistan

Isomiddin Jurayev

2nd Year Master's Student, English Language Faculty, Fergana State University, Uzbekistan

\section{ABSTRACT}

Semantic change refers to any change in the word meaning and that change happens over the course of many years. Semantic change is studied in historical linguistics and semantics also it is called by different names as semantic shift, lexical change, semantic progression and there are many types of semantic changes amelioration, pejoration, broadening, semantic narrowing, bleaching, metaphor and metonymy. Language learner's also causes to semantic change while interpreting the expression or words because people have different background, diverse nations have diverse culture. In this article some features of the semantic progression of verbs are explained.

KEYWORDS: - Semantic shift, change, metaphor, metonymy, meaning, verb, common vocabulary.

\section{INTRODUCTION}

For example technology has appeared and after the invention of laptop especially a mouse (sichqoncha) used to control the monitor and now the meaning of it changes to verb and using the mouse in computer usage called as a verb "to mouse". That can be a sample for semantic change. Semantic change is not immediately recognized by all member of a language users or native speakers. An innovation enters into a language and spreads through the speech community along socially determined lines. The original meaning of a form is not immediately displaced by the innovated meaning, but the two coexist for some time. "Semantic change is not a change in meaning per se, but the addition of a meaning to the semantic system or the loss of a meaning from the semantic system while the form remains constant."[1]

\section{RESEARCH METHODOLOGY}

The role of metaphor in semantic change is great. Because once writer uses a word in a metaphoric change over time that can be accepted the language community. For example, see means watching something by using visual aid with our eyes but metaphorically it has another meaning called understanding. Orally, mainly I see is used as an option of understanding something by many native and nonnative language users. In forma way it is not accepted yet but if someone says he saw it then 
CURRENT RESEARCH JOURNAL OF PHILOLOGICAL SCIENCES 2(11):

150-152, November 2021

DOI: https://doi.org/10.37547/philological-crjps-02-11-32

ISSN 2767-3758

(C)2021 Master Journals

Crossref do

gil Google

Accepted25 ${ }^{\text {th }}$ November, 2021 \& Published $30^{\text {th }}$ November, 2021

that may be understandable by hearer within a context but in formal way or written speech it is accepted as by using eyes he watched something. So in this article oral usage if verbs and contexts with the written speech compared to each other. "Metaphor in semantic change involves extensions in the meaning of a word that suggest a semantic similarity or connection between the new sense and the original one. Metaphor is considered a major factor in semantic change...The semantic change of grasp 'seize" to 'understand,' thus can be seen as such a leap across semantic domains, from the physical domain ('seizing') to the mental domain ('comprehension')... Frequently mentioned examples of metaphoric extensions involve expressions for 'to kill': dispose of, do someone in, liquidate, terminate, take care of, eliminate and others."[2]

\section{Results}

Semantic shift occurs mainly in different ways

\section{Lack of knowledge on something}

For example: Baking a bread in Uzbek language go under different stages as Xamir qilmoq, non yasamoq, zuvala olmoq, yoymoq, nampar urmoq, suv sepmoq, nonni uzmoq nearly ever uzbek household bakes bread so they now the verbs to describe baking process however it is not the same with Brits cause in their daily lifestyle baking is not widespread.

2. Metaphor-over time some metaphor evolves into common vocabulary for example recently I heard in English conversation native people are talking about an extinct bird Dodo and then I realized that they used it to describe dead, vanished thing not bird. Here is a that sentence "I found my Dodo book in my childhood staff " explanation of this sentence is that person lost that book before.

\section{Difference in viewpoint}

"Semantic shift also occurs in certain ordinate and superordinate nouns. For example, 'Christian' is a superordinate term in British English and refers to all followers of the Christian religion, no matter to which branch or sect of it they belong. In Singaporean English, 'Christian' specifically refers to Protestant (Deterding, 2000). Similarly, 'alphabet' in English refers to the whole system of letters while in Singaporean English it refers to any one of them. This, in Singaporean English, the word 'alphabet' is made up of 8 alphabets."

\section{Conclusion}

Although semantic change has a great importance in verb meaning, it is sometimes unpredictable. Because linguists hold various opinions on certain issue so may that change accepted or rejected by a group of scholars. "Traditional approaches to semantic change typically focus on outcomes of meaning change and list types of change such as metaphoric and metonymic extension, broadening and narrowing, and the development of positive and negative meanings. Examples are usually considered out of context, and are lexical members of nominal and adjectival word classes. So Traditional approaches to semantic change typically focus on outcomes of meaning change and list types of change such as metaphoric and metonymic extension, broadening and narrowing, and the development of positive and negative meanings. Examples are usually considered out of context, and are lexical members of nominal and adjectival word classes. [4] Example: may modal verb has originally the meaning of possibility and then after semantic change new "permission" meaning existed.. . She may go- probably she will go or the allowance to exit. "Short-term semantic shift is a complex phenomenon, and understanding the nature of it implies a lot of challenges. Our findings suggest that significant frequency increase is not necessarily followed by significant change in usage, and relatively constant frequencies over time do not imply stability of contextual meaning. We showed 
CURRENT RESEARCH JOURNAL OF PHILOLOGICAL SCIENCES 2(11):

150-152, November 2021

DOI: https://doi.org/10.37547/philological-crjps-02-11-32

ISSN 2767-3758

(C)2021 Master Journals

Crossref dit) 81 Google

Accepted $25^{\text {th }}$ November, 2021 \& Published $30^{\text {th }}$ November, 2021

that dynamics of word usage is a possible indicator of wider socio-cultural or political shifts."[5]

\section{REFERENCES}

1. David P. Wilkins, "Natural Tendencies of Semantic Change and the Search for Cognates" in The Comparative Method Reviewed, ed. by M. Durie and M. Ross. Oxford University Press, 1996 44p.

2. Lyle Campbell, Historical Linguistics: An Introduction. MIT Press, 2004 99p.

3. Andy Kirkpatrick, World English. Cambridge University Press, 2007 134p.

4. Elizabeth.C.T, Semantic Change. 2017 4p.

5. Anna Marakasova . Short-term Semantic Shifts and their Relation to Frequency Change [6]

6. Allan, K., \& Robinson, J. A. (Eds.). (2012). Current methods in historical semantics. Berlin, Germany: De Gruyter Mouton.

7. Blank, A., \& Koch, P. (Eds.). (1999). Historical semantics and cognition. Berlin, Germany: Mouton de Gruyter.

8. Deo, A. (2015). Formal semantics/pragmatics and language change. In C. Bowern \& B. Evans (Eds.), Routledge handbook of historical linguistics (pp. 393-409). London, U.K.: Routledge.

9. Detges, U., \& Waltereit, R. (2011). Turn-taking as a trigger for language change. In S. D. Schmid, U. Detges, P. Gévaudan, W. Mihatsch, \& R. Waltereit (Eds.), Rahmen des Sprechens: Beiträge zu Valenztheorie, Varietätenlinguistik, Kreolistik, Kognitiver und Historischer Semantik (pp. 175-189). Tübingen, Germany: Narr.

10. Fitzmaurice, S. M. (2016). Semantic and pragmatic change. In M. Kytö \& P. Pahta (Eds.), The Cambridge handbook of English historical linguistics (pp. 256-270). Cambridge, U.K.: Cambridge University Press.
11. Hansen, M.-B., Mosegaard, J., \& Visconti, J. (Eds.). (2009). Current trends in diachronic semantics and pragmatics. Bingley, U.K.: Emerald Group.

12. Heine, B., Claudi, U., \& Hünnemeyer, F. (1991). From cognition to grammar: Evidence from African Languages. In E. C. Traugott \& B. Heine (Eds.), Approaches to grammaticalization (Vol. 1, pp.149-187). Amsterdam, Netherlands: Benjamins.

13. Hans Henrich Hock and Brian D. Joseph, Language History, Language Change, and Language Relationship. Walter de Gruyter, 1996.

14. Rasuljanovna, I. N. (2019). Lacunas Occurance In Semantic Fields of Chinese And Uzbek Languages. International Journal of Scientific \& Technology Research, 8(11), 1998-2001. 